\title{
A Study on the Optimal Ratio of Research and Development Investment in the Energy Sector: An Empirical Analysis in South Korea
}

\author{
Juyong Lee ${ }^{1}\left(\mathbb{D}\right.$, Youngsang Cho ${ }^{1, *}$ and Jungwoo Shin ${ }^{2}(\mathbb{C}$ \\ 1 Department of Industrial Engineering, College of Engineering, Yonsei University, 50 Yonsei-Ro, \\ Seodaemun-gu, Seoul 03722, Korea; dlwndyd@yonsei.ac.kr \\ 2 Department of Industrial and Management Systems Engineering, College of Engineering, \\ Kyung Hee University, 1732 Deogyeong-daero, Giheung-gu, Yongin, Gyeonggi 17104, Korea; \\ shinjung11@khu.ac.kr \\ * Correspondence: y.cho@yonsei.ac.kr; Tel.: +82-2-2123-5727; Fax: +82-2-364-7807
}

Received: 2 December 2018; Accepted: 11 January 2019; Published: 17 January 2019

\begin{abstract}
The necessity for energy research and development (ER\&D) is increasing as greenhouse gases and climate change are becoming global issues. To support sustainable economic growth through ER\&D, it is necessary to examine the optimal ratio of ER\&D investment to total R\&D investment to maximize economic growth. However, there are no studies on the appropriate level of ER\&D in total R\&D investment for economic growth. This study attempts to empirically estimate the optimal ratio of ER\&D investment to maximize gross domestic product (GDP) in South Korea. We utilized the Cobb-Douglas production function for our econometric model and corrected the autocorrelation problem using the Cochrane-Orcutt iterative procedure. Our results showed that both, ER\&D and non-ER\&D have positive correlations with GDP. The optimal ratio of ER\&D is derived as $13.23 \%$, which indicates that the current ratio of Korean ER\&D should be revised upward. Further, ER\&D investment in the private sector needs to be increased to achieve the optimal ratio because the current statistics in Korea describes that private companies in the energy industry invest much less in R\&D than the government. Based on the results, we suggest government strategies to enhance ER\&D investment in the private sector as well as the public sector.
\end{abstract}

Keywords: optimal ratio; research and development; energy industry; production function; delta method

\section{Introduction}

The global energy industry, which has relied on large-scale fossil fuel plants, is undergoing a paradigm shift due to climate change. There has been increasing interest in renewable energy, represented by solar, wind, and hydro, starting with the Paris Agreement in which 175 countries participated in making a commitment toward the reduction of $\mathrm{CO}_{2}$ [1]. In addition, the G20 Hangzhou Summit in 2016 included a statement on phasing out the generation of coal power through the rational adjustment of ineffective fossil fuel subsidies which had encouraged wasteful energy consumption [2]. In order to cope with climate change, the member countries planned to expand research and development (R\&D) investment in renewable energies and technologies to improve energy efficiency, reduce greenhouse gas, and foster the development of a new energy industry.

The importance of energy $R \& D(E R \& D)$ investment is increasing since it is necessary to deal with global energy trends appropriately for sustainable economic growth. There are many studies on the relationship between $R \& D$ investment and economic growth [3-6]. These studies have validated the fact that $R \& D$ investment has a positive effect on economic growth, and thus, increases in R\&D investment have become more relevant. In addition, many researchers have conducted quantitative 
and qualitative analyses to verify the positive relationship between ER\&D investment and economic growth [7-9]. However, considering the importance of R\&D and ER\&D investment, studies on their proper level are relatively insufficient. In fact, Bor et al. concluded that R\&D investment above the threshold has an adverse effect on economic growth [10]. In other words, an appropriate level of R\&D investment is needed for economic growth.

The purpose of this study is to analyze the relationship between ER\&D investment and economic growth in light of econometrics, and to estimate the optimal ratio of ER\&D investment to total R\&D investment to maximize economic growth in the case of South Korea. To estimate the optimal ratio, we assume that there is a concave-downward relationship between ER\&D investment and economic growth. In other words, GDP increases with ER\&D investment to a certain point and then begins to decrease, and this point is the optimum ER\&D for maximizing economic growth. The rest of this paper is organized as follows: Section 2 gives previous studies on global trends in the energy industry, and the effects of R\&D and ER\&D on economic growth. Section 3 explains the research model that is based on the model proposed by [11]. Section 4 presents the empirical results on the optimal ratio of ER\&D in South Korea. In Section 5, we discuss conclusions of our research and suggest some directions for future research.

\section{Backgrounds}

\subsection{Global Trends in the Energy Industry}

Through the Paris Agreement, the parties agreed to set and check their Nationally Determined Contributions (NDCs), which are voluntary greenhouse gas reduction targets, once every five years [12]. Since the global average temperature is expected to rise by 2.7 degrees Celsius by the year 2100, more efforts for reduction are required to lower the average temperature. The parties submitted their NDCs in various forms, such as intensive targets compared to BAU, reduction targets, absolute targets, and unit level targets $[13,14]$. Table 1 shows the NDC targets for major countries. In order to achieve these NDC targets, the parties are implementing measures such as improving carbon intensity, expansion of renewable energy sources, improving energy efficiency, and revising fuel consumption standards [15].

Table 1. NDC targets for major countries [15].

\begin{tabular}{cccc}
\hline \multirow{2}{*}{ Countries } & NDC Targets & \multicolumn{2}{c}{ Carbon Emissions (Gt) } \\
\cline { 3 - 4 } & & $\mathbf{2 0 1 4}$ & 2030 Targets \\
\hline United States & $\begin{array}{c}\text { 26-28\% reduction by } \\
2025 \text { compared to 2005 }\end{array}$ & 5.7 & 5.0 \\
\hline Japan & $\begin{array}{c}26 \% \text { reduction by 2030 } \\
\text { compared to 2013 }\end{array}$ & 3.3 & 2.5 \\
\hline EU & $\begin{array}{c}40 \% \text { reduction by 2030 } \\
\text { compared to 1990 }\end{array}$ & 1.2 & 0.9 \\
\hline China & $\begin{array}{c}\text { 60-65\% reduction by } \\
\text { 2030 compared to 2005 }\end{array}$ & 9.8 & 10.1 \\
\hline
\end{tabular}

Decarbonization is required in power, transportation, industry, and building, in order to achieve NDC targets [16]. The power sector is expected to undergo the strongest decarbonization process when compared to other sectors [17]. Additional reduction measures include the improvement of carbon intensity of power plants and the reduction of power demand by efficiency improvement. Decarbonization in the transportation sector is expected to slow down due to the increased demand for transportation in developing countries $[18,19]$. Additional reductions are expected to be achieved through the expansion of electric vehicles (EVs) and the commercialization of biofuels. Biofuels are recognized as essential sources of energy for decarbonization of aviation, marine, and cargo industries, 
although it is still at the initial level of technology [20]. Although the industrial sector emits a large amount of carbon, decarbonization is expected to be slow because there is a limit on the application of carbon reduction measures [21]. Carbon intensity in the industrial sector is steadily increasing, even in the effort to promote decarbonization, based on efficiency improvement [22]. Therefore, fuel conversion and commercialization of carbon capture and storage (CCS) technology are needed for further carbon reduction [23].

In South Korea, the focus of the energy policy is to reduce nuclear power use and coal power generation and to increase the portion of renewable energies such as wind and solar power [24,25]. The amount of electricity produced by wind and solar is only about $1 \%$ of the total at present, and thus, the Korean government is planning to intensively raise the ratio of renewable energy to $20 \%$ of the total electric power by 2030 [26]. To achieve this plan, policies such as permission of unlimited network connection of small-scale renewable energy complexes, expansion of renewable portfolio standard (RPS) ratio, and the introduction of feed-in tariffs (FITs) system are underway. In addition, the Korean government is preparing to enter the era of smart grids and is constructing an energy ecosystem to prepare for digital transformation [27]. Korea is constructing a platform-based energy system that integrates both internet and the energy industry and is promoting an expanded supply of artificial intelligence programs that automatically analyze the demand for electricity.

\subsection{ERED and Economic Growth}

Various studies have been conducted on the impacts of R\&D and ER\&D investment on economic growth. First, it is necessary to figure out the relationship between the total R\&D investment and economic growth. Mansfield analyzed the relationship among R\&D investment, productivity improvement, and economic growth in the United States [3]. Based on a meta-analysis, he explained that R\&D investment plays a significant role in both economic growth and the improvement of productivity. In addition, he also found that there is a trend of underinvestment in the private sector in R\&D, and thus, it needs to be improved gradually. Bilbao-Osorio and Rodríguez-Pose analyzed the effect of R\&D investment on innovation based on the Cobb-Douglas production function [4]. They regarded the number of patents per one million population as a proxy for innovation competence. They concluded that R\&D investment and innovation have a positive relationship, which leads to economic growth. Griffith et al. also analyzed the impact of R\&D investment on innovation [23]. They estimated a production function, using data from 12 OECD (Organization for Economic Cooperation and Development) countries. They demonstrated that R\&D investment has a direct impact on innovation and an indirect impact on technology transfer. They concluded that R\&D investment is a key factor in increasing total factor productivity (TFP). Krrístková studied the relationship between R\&D investment and economic growth, based on the Computable General Equilibrium (CGE) model [6]. He concluded that R\&D investment has a significant effect on knowledge accumulation and that R\&D investment and GDP growth have a positive relationship in the long run. Previous studies such as $[28,29]$ validated that increasing R\&D investment is a key factor in enhancing productivity, innovation, and GDP, which have been utilized as economic indicators.

In case of the energy industry, studies in the recent decade have focused on the balance between the supply of and demand for energy, rather than on the effect of R\&D investment. However, some previous studies have emphasized the importance of ER\&D investment by analyzing the relationship between ER\&D and economic growth. Dooley demonstrated that the reduction or failure of ER\&D investment has negative effects on achieving goals pertaining to the environment, healthcare, and national economy [7]. He emphasized that sufficient public ER\&D should be supported to enhance innovative energy systems that resolve climate change. Schuelke-Leech analyzed recent 15 -years-ER\&D-data in the U.S. government to compare the ratios of public ER\&D investment by industrial sectors [8]. He figured out that most companies tend to be reluctant when it comes to investing in ER\&D due to the uncertain rate of return. Accordingly, he concluded that the increasing ratio of the public ER\&D investment and adequate funding in the industrial sectors are essential for 
technical innovation and economic growth. Wong et al. conducted research to analyze the relationship between ER\&D and economic growth [9]. Based on the Nerlove partial adjustment model (NPAM) and panel regression, they substantiated that there is a significant and dynamic linkage between ER\&D and economic growth. Additionally, they concluded that the consumption of renewable energy, rather than fossil fuel energy, is the core element for economic growth.

However, there are some interesting studies emphasizing that overinvestment in public R\&D can have either no or adverse effects on economic growth. Bor et al. analyzed the relationship between public R\&D investment and economic growth in Taiwan based on the CGE model [10]. They increased the amount of R\&D investment by $1 \%$ annually from the year 2008 and estimated the GDP. During the first three or four years, the GDP had increased but then decreased gradually. They concluded that an inappropriate increase in the $R \& D$ investment can cause a negative impact on economic growth from a long-term point of view. In addition, refs. [30-32] have also analyzed the impact of public R\&D on TFP and GDP, which represent the economic growth of nations. They found that private R\&D, rather than government R\&D, has a positive and significant impact on economic growth.

\subsection{Global Status of ERED}

Strengthening both scientific technology and the capability of R\&D has recently emerged as a key solution for innovation and sustainable growth, resulting in an annual increase in the global total R\&D investment $[33,34]$. However, the ratio of ER\&D investment in total R\&D investment tends to decrease although the energy industry is one of the most important industries for sustainable economic growth. As Figure 1 shows, the total ER\&D budget of major OECD member countries recorded 15.32 billion USD in 2009, which is the maximum amount by the American Recovery and Reinvestment Act but has decreased since 2013 [35]. Although the absolute amount of the budget remains higher when compared with those in past decades, the ratio of ER\&D investment to total R\&D investment in 2016 declined to $4.64 \%$ from $10.57 \%$ in 1981 [35].

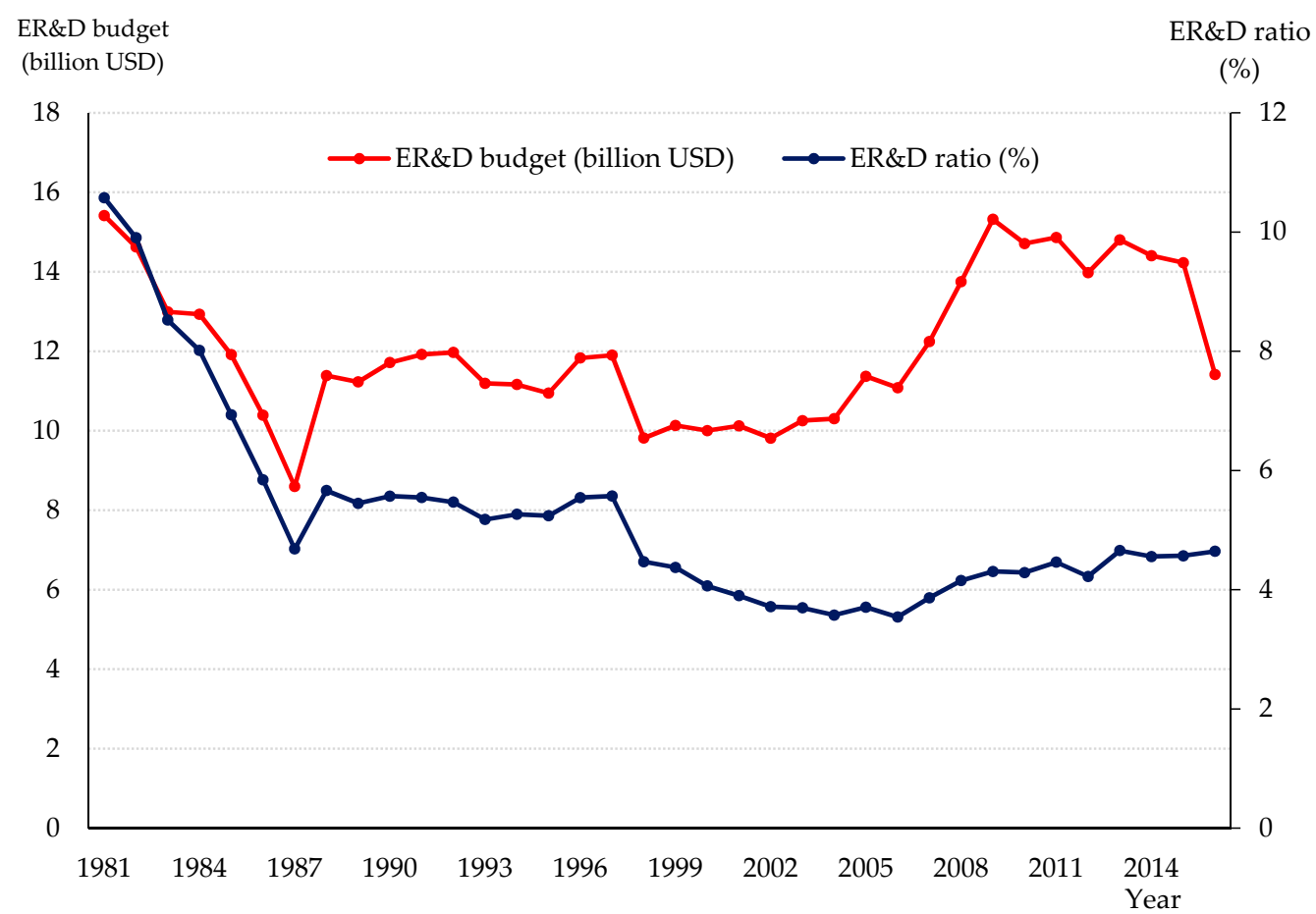

Note: R\&D stands for Research and Development; ER\&D stands for Energy Research and Development; OECD stands for Organization for Economic Cooperation and Development.

Figure 1. ER\&D budget and the ratio of ER\&D investment to total R\&D investment in OECD countries [35]. 
In particular, ER\&D in South Korea is also in a similar situation when compared to the global ER\&D tendency. In 2015, the amount of R\&D investment in the public and private sector recorded 18.87 trillion Korean won (KRW; the yearly average exchange rate in 2015 was $1131.16 \mathrm{KRW} / \mathrm{USD}$, https: / / data.oecd.org/ conversion/ exchange-rates.htm) and 47.09 trillion KRW, each. The total amount of R\&D investment, including the public and private sectors, recorded 65.96 trillion KRW and took the fifth-highest among the OECD countries [35]. The annual growth rate of the total R\&D investment during the last five years was $8.51 \%$, with consistent growth. Furthermore, the ratio of the total R\&D investment to GDP increased from $2.20 \%$ in 1995 to $4.22 \%$ in 2015, which held the second rank among the OECD countries [35]. These statistical records show that South Korea has made considerable investments in R\&D in recent times. However, as Figure 2 shows, the ratio of ER\&D investment to total R\&D investment decreased from $6.46 \%$ in 2010 to $5.94 \%$ in 2015 [36]. Under the current circumstances, considerations and discussions on whether this tendency of ER\&D investment in South Korea is rational and what is the optimal ratio of ER\&D investment ultimately are required in order to develop and improve energy technologies and to achieve economic growth.

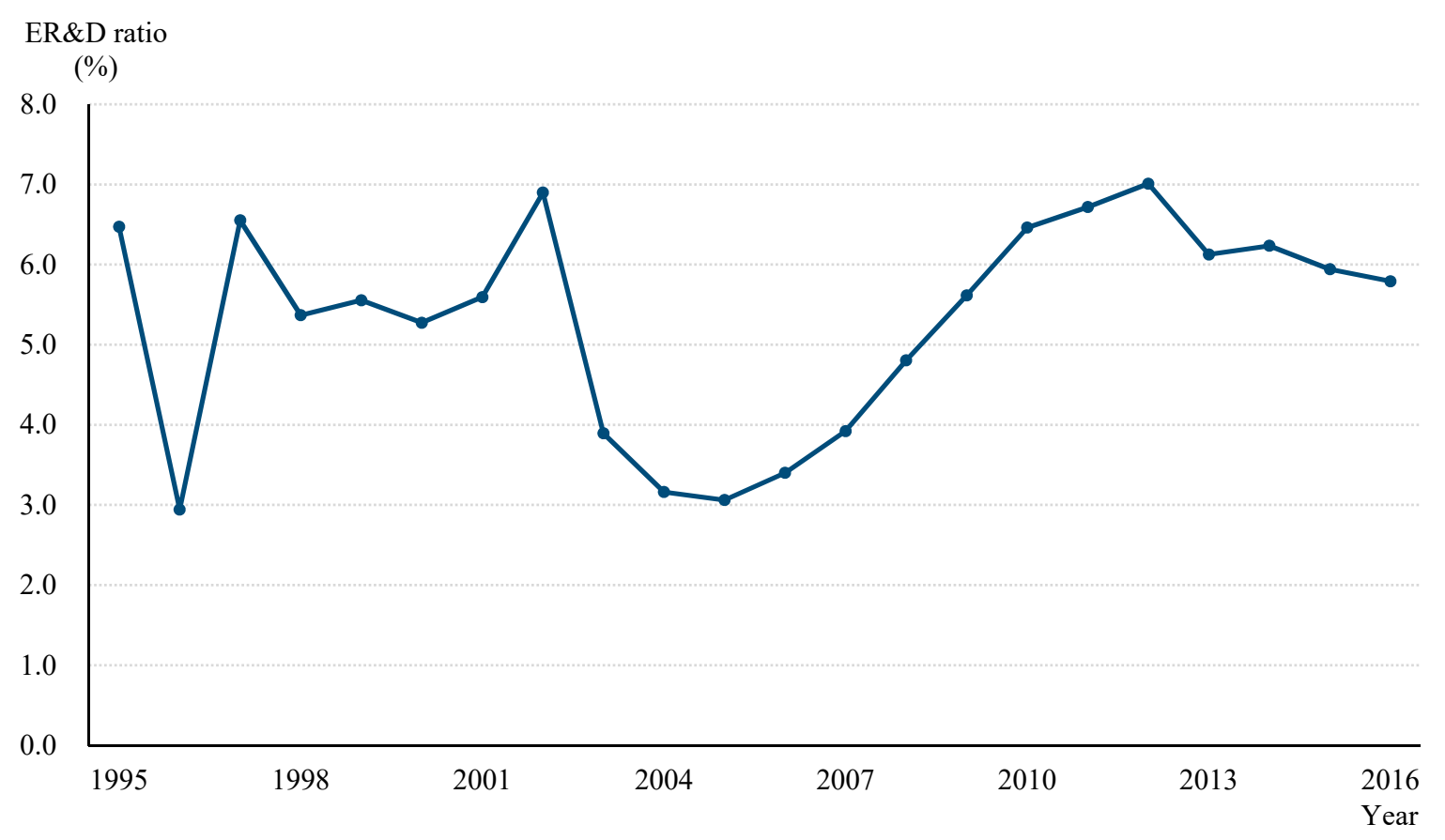

Figure 2. The ratio of ER\&D investment to total R\&D investment in South Korea [36].

The validity of increasing R\&D investment properly, especially in the energy sector, has been corroborated by previous studies. In addition, analyzing the proper level of ER\&D for economic growth and drawing up related energy policies based on the analyses are required. However, to the best of our knowledge, no study has yet proposed the optimal ratio of ER\&D investment for economic growth. In this situation, this study estimates the optimal ratio of the ER\&D investment for maximizing economic growth in South Korea using a model proposed by Scully [11].

\section{Methodology}

Scully assumed that the annual gross national product (GNP) increases with the national average tax rate to a certain level and then begins to decrease [11]. Scully's model, which is based on the Cobb-Douglas production function, has been widely used in various studies because the values of the independent variable that maximize the dependent variable can be estimated via this model [37-40]. In this study, we modified the model to estimate the ratio of ER\&D investment for maximizing economic growth. 
In this study, we consider labor input $\left(L_{t}\right)$, capital stock $\left(K_{t}\right)$, and total $R \& D$ investment $\left(R D_{t}\right)$ as the factors affecting GDP at time $t$. Then, we assume that the total $R \& D, R D_{t}$, is divided into ER\&D investment $\left(E R D_{t}\right)$ and non-ER\&D investment $\left(N E R D_{t}\right)$, and $\lambda$ stands for the ratio of ER\&D investment to the total R\&D investment. Thus, the amount of ER\&D investment at time $t$ can be described as $\lambda R D_{t}$ and the amount of non-ER\&D investment can be described as $(1-\lambda) R D_{t}$. To analyze the impacts of labor input, capital stock, and the R\&D investment on GDP, we form a function as follows:

$$
G_{t}=F\left(L_{t}, K_{t}, R D_{t-p} ; A(t)\right)=F\left(L_{t}, K_{t}, E R D_{t-p}, N E R D_{t-p} ; A(t)\right),
$$

where $G_{t}$ is GDP in year $t$, which is a representative indicator of national economic status, and $A(t)$ stands for the impacts of other factors, except labor input, capital stock, and R\&D investment. In addition, lower subscript $p$ indicates the time lag between R\&D investment and GDP. Assuming that the relationships among the factors and the GDP follow the Cobb-Douglas production functional form, then Equation (1) can be expressed as follows:

$$
G_{t}=A(t) \cdot L_{t}^{\alpha} \cdot K_{t}^{\beta} \cdot E R D_{t-p}^{\gamma} \cdot N E R D_{t-p}^{\delta} .
$$

Since the Cobb-Douglas production function indicates a decreasing return to scale, $\alpha, \beta, \gamma$ and $\delta$ take values between 0 and 1 . In order for the ER\&D investment to have maximum value, the first partial derivative regarding the ER\&D should be greater than 0 , and the second partial derivative should be lower than 0 . We can derive the conditions for the first and second derivatives of the ER\&D investment to have maximum value as expressed in Equations (3) and (4):

$$
\begin{gathered}
\frac{\partial G_{t}}{\partial E R D_{t-p}}=\gamma \frac{G_{t}}{E R D_{t-p}}>0 \\
\frac{\partial^{2} G_{t}}{\partial\left(E R D_{t-p}\right)^{2}}=-\gamma \frac{G_{t}}{\left(E R D_{t-p}\right)^{2}}<0
\end{gathered}
$$

Consequently, there is a concave-downward relationship between ER\&D and economic growth, and the point at which the economic growth begins to decrease as the ER\&D increases, is the optimum for maximizing economic growth. To find the optimal point of the ratio of ER\&D investment, we take the natural logarithm of Equation (2) as follows:

$$
\begin{gathered}
\ln G_{t}=\ln A+\alpha \ln L_{t}+\beta \ln K_{t}+\gamma \ln E R D_{t-p}+\delta \ln N E R D_{t-p} \\
=\ln A+\alpha \ln L_{t}+\beta \ln K_{t}+\gamma \ln \lambda R D_{t-p}+\delta \ln (1-\lambda) R D_{t-p} \\
=\ln A+\alpha \ln L_{t}+\beta \ln K_{t}+\gamma \ln \lambda+\gamma \ln R D_{t-p}+\delta \ln (1-\lambda) R D_{t-p}
\end{gathered}
$$

The optimal point for maximizing economic growth is satisfied when the partial derivative of the GDP with respect to $\lambda$ is equal to 0 . This condition of the partial derivative is expressed as follows:

$$
\frac{\partial G_{t}}{\partial \lambda}=\frac{\gamma}{\lambda}-\frac{\delta}{1-\lambda}=0 \stackrel{\text { yields }}{\rightarrow} \lambda^{*}=\frac{\gamma}{\delta+\gamma} .
$$

Here, the value $\lambda^{*}$ stands for the optimal ratio of ER\&D investment, and we can estimate $\lambda^{*}$ by using the delta method via the parameters $\gamma$ and $\delta$. The delta method is widely used by statisticians and scientists for calculating the variance of parameters [41-43].

\section{Research Findings}

\subsection{Data}

To estimate the optimal ratio of ER\&D investment, data on GDP, labor input, capital stock, ER\&D, and non-ER\&D are required. We obtained the real GDP data by dividing the nominal GDP by the 
GDP deflator of 2010. We obtained the labor input by multiplying the total number of employed workers and the average yearly working days. Capital stock was calculated by multiplying the sum of construction assets, facilities assets, and intellectual property products by the average manufacturing capacity utilization rate. Theoretically, multiplying the average capacity utilization rate of the total industry is more appropriate for an accurate analysis, but we used the capacity utilization rate of manufacturing industry due to the insufficient data problem. This assumption is used in existing studies to calculate the capital stock of total industry while conducting an analysis based on the production function [44,45]. We used the data provided by the Korean Statistical Information Service while calculating the real GDP, labor input, and capital stock. The R\&D data are provided by National Science and Technology Information Service, and the criteria to divide the industry into energy and non-energy are based on a Standard Science and Technology Classification of Korea. The Standard Science and Technology Classification of Korea classifies industries into electricity, communication, machinery, chemicals, materials, health, energy, construction, food, environment, nuclear power, physics, culture, earth science, economics, and education. In this study, all sectors except for the energy are defined as non-energy industries. The time period of this study ranges from 1995 to 2015, and we included a dummy variable for the economic crisis to reflect the effect of the Asian financial crisis in 1997 and the global financial crisis in 2008.

\subsection{Analysis Results}

Based on the Cobb-Douglas production function, we estimate the optimal ratio of ER\&D investment by analyzing the impacts of labor input, capital stock, ER\&D investment, and non-ER\&D investment on GDP in Korea. Considering that our data are time-series data, there is a high possibility of autocorrelation problems which are correlations among the sets of variables arranged by time [46]. Therefore, in this study, we use the Cochrane-Orcutt iterative procedure for estimation [47].

R\&D activities require a considerable amount of time from basic research, for commercialization and profit generation. The average time from the $R \& D$ investment to the start of generating returns is defined as the R\&D gestation lag [48]. However, the time lag differs across different stages in the R\&D procedure, which are, basic research, applied research, and development research. Furthermore, even in the same stage, there are differences across fields or industries. Thus, it is difficult to derive the accurate R\&D gestation lag. In 1999, Korea Industrial Technology Association (KOITA) analyzed 775 companies in Korea and the estimated R\&D gestation lag was about 3.51 years [49]. The lag is calculated by the sum of the lags of three stages; 24.17 months for the basic research stage, 12.15 months for the applied research stage, and 5.80 months for the development research stage. Based on the estimated results in the previous studies, we estimate the optimal ratio of ER\&D investment by assuming the ER\&D gestation lag as four years and the non-ER\&D gestation lag as three years, reflecting that the lag of ER\&D is relatively longer here than in other industries [50]. We also performed additional analyses by setting the gestation lags from two to seven years, but none of them was statistically significant except the result we present in this study.

The estimation results are presented in Table 2. As a result of the Cochrane-Orcutt iterative procedure, the Durbin-Watson statistic was corrected from 1.166 to 1.816 (the Durbin-Watson statistic has a value between 0 and 4 , and has a value of 2 when there is no autocorrelation [51,52]), which is close to the reference value of 2 . Therefore, the independence between residuals is maintained, so we can ignore the autocorrelation problems of time-series data.

Among the variables used in the analysis, capital stock, ER\&D investment, and non-ER\&D investment are statistically significant. Coefficients of these variables are positive, which indicates that the capital stock, ER\&D investment, and non-ER\&D investment have positive effects on economic growth. This result is consistent with the results in previous studies, which is that $R \& D$ has a positive impact on economic growth $[3,23,29]$. Whereas labor input is not statistically significant, and we can say that the economic growth of South Korea is no longer driven by labor input [53]. In addition, the coefficient of the economic crisis is negative but not statistically significant. 
The optimal ratio of ER\&D investment to total R\&D investment is derived by Equation (6) with the delta method, using the results in Table 2. The estimated optimal ratio of ER\&D investment to total R\&D investment is about $13.23 \%$, which is statistically significant ( $t$-value: $2.16, p$-value: 0.03 ).

Table 2. Estimation results of the Cochrane-Orcutt iterative procedure.

\begin{tabular}{|c|c|c|c|}
\hline \multirow{2}{*}{$\begin{array}{c}\text { Variable } \\
\text { Constant }\end{array}$} & \multicolumn{2}{|c|}{ Coefficient } & \multirow{2}{*}{$\frac{t \text {-Value }}{2.25}$} \\
\hline & 6.2250 & * & \\
\hline $\ln L_{\mathrm{t}}$ & -0.1890 & & -1.09 \\
\hline $\ln K_{t}$ & 0.4553 & $* *$ & 4.05 \\
\hline $\ln E R D_{\mathrm{t}-\mathrm{p}}($ Energy) & 0.0279 & * & 2.51 \\
\hline $\ln N E R D_{\mathrm{t}-\mathrm{p}}$ (non-Energy) & 0.1795 & $* *$ & 3.74 \\
\hline Economic crisis & -0.0010 & & -0.07 \\
\hline Rho & & 0.3975 & \\
\hline Observed value & & 16 & \\
\hline Adjusted R-squared & & 0.9871 & \\
\hline
\end{tabular}

\section{Discussion}

In South Korea, the actual ratio of ER\&D investment to total R\&D investment in 2015 was $5.94 \%$ which is less than the half of the estimated optimal ratio of $13.23 \%$. On the other hand, in the government R\&D (public R\&D) excluding private $R \& D$, the ratio of ER\&D is about $8.25 \%$ which is still lower than the optimal ratio, but is about $40 \%$ higher than the ratio based on total ER\&D [36]. This shows that private companies in the energy industry invest in R\&D far lesser than the government does. One of the main reasons for this is that the R\&D in the energy industry does not bring about rapid profitability due to the long gestation lag when compared to other industries [50,54]. As a result, the private sector tends to be reluctant to invest in ER\&D. In order to maximize economic growth, it is difficult to raise the ratio of ER\&D investment to the optimal level by increasing investment in either the private or the public sector. Therefore, it is necessary for the government to implement policies such as tax exemption, R\&D infrastructure, or subsidy support to encourage companies to increase ER\&D in the private sector. At the same time, the government also needs to increase its investment in ER\&D to increase the proportion of energy in the total R\&D investment.

Governments in many countries have elicited ER\&D investments in the private sector by implementing policies and providing financial benefits such as tax incentives and subsidies. In 2016, Germany has settled 30 million Euros for residential solar photovoltaic (PV) co-operations linked to the energy storage system (ESS) [55]. The French government operated a tax credit system (Tax Credit for Energy Transition, CITE) reducing a certain percentage of the income tax of investors who had invested in renewable energy generation facilities [56]. Since January 2016, the French government has supported subsidies and approved trading electricity directly in the market, so that renewable energy companies can preserve the profitability of investment [57]. The United Kingdom introduced FITs with contracts for difference (CFD) as measures to elicit investment needed to replace old facilities and expand low-carbon energy sources [58]. The CFD is contracted between renewable energy companies and government-owned low-carbon contractors, and the companies receive the difference between the reference price and the strike price for 15 years [59].

Developing countries are also implementing their policies and support for private ER\&D investment. India has launched a 3 billion USD Pradhan Mantri Yojana for Augmenting Solar (PRAYAS) Initiative, which fosters its own solar panel manufacturing companies [60]. This program focuses on raising the production capacity of the PV sector in India and promotes it as an export industry. Mexico 
aims to convert $5 \%$ of its energy usage to renewable energy by 2018 , and $35 \%$ or more of all energy produced in Mexico is expected to be converted to renewable energy by 2024 [61]. To achieve these aims, more than 50 energy-related $R \& D$ projects were implemented in 2016, and the energy policies have been modified to allow the private sector to participate in national energy projects. In terms of ER\&D expenditure, Mexico was the highest with 18.80\% among OECD countries in 2015 [35].

The common finding from countries implementing policies to elicit ER\&D investment in the private sector is that they have increased investment in renewable energy. However, considering the distinct characteristics of the energy industry in South Korea, additional analyses should be performed to find out which approaches to renewable energy, among tax incentives, subsidies, R\&D project promotion, and others, can facilitate the increase of ER\&D investment in the private sector. Additionally, preliminary investigations and analyses of factors that discourage investment in renewable energies and whether the national budget for implementing R\&D for renewable energy is cost-effective in South Korea are also needed.

\section{Conclusions}

As environmental issues such as climate change and renewable energy are emerging globally, the need for R\&D in the energy industry is also increasing. There are studies showing that ER\&D has a positive impact on economic growth, but there are also studies showing that the overinvestment in R\&D can have adverse effects the economic growth [10,31]. Although the importance of the energy industry has been increasingly emphasized for sustainable economic growth [7-9], no study on proper ER\&D investment has yet been proposed, to the best of our knowledge. Therefore, this study conducted an empirical analysis of the optimal ratio of ER\&D investment to total R\&D investment in South Korea based on the Cobb-Douglas production function. For this, we corrected the autocorrelation problem that occurs due to the time-series data through the Cochrane-Orcutt iterative procedure.

The estimation results showed that both ER\&D and non-ER\&D have positive effects on economic growth, and are statistically significant. Using the model proposed by [11], the optimal ER\&D ratio to the total R\&D investment is derived as $13.23 \%$. Considering the fact that the ER\&D ratio was about $5.94 \%$ in South Korea, this ratio should be revised upwards to support economic growth. We also found that it is necessary to increase the ER\&D investment in the private sector to achieve the optimal level of ER\&D in South Korea.

The main contribution of this study is that we successfully estimated the optimal ratio of ER\&D investment to total R\&D investment in South Korea. This study provides an empirical basis for the necessity to increase R\&D investment in the energy industry. In addition, the results derived in this study can be utilized in future government R\&D budget decisions and energy-related policies.

This study has some limitations. First, we categorized the R\&D into ER\&D and non-ER\&D. In South Korea, annual data on detailed ER\&D investment by energy sources such as coal, nuclear, water, and solar have not been published. However, it is necessary to estimate the optimal ratio of the $R \& D$ by each energy source in studies in the future, because the recent $R \& D$ on renewable energies is increasing globally. Second, we used data up to the year 2015. It is necessary to cover data from more recent years for more reliable results, but the Korean annual R\&D report was published up to 2015, as of the time of analysis. Third, in the process of calculating the capital stock, the average capacity utilization rate of the manufacturing industry was used due to the lack of data. For a more accurate analysis, it is necessary to use the average capacity utilization rate of the entire industry. Lastly, it is necessary to verify our estimation results through a comparison with other countries. It is expected that more generalized results can be obtained by an analysis of panel data from other countries, including South Korea.

Author Contributions: J.L. and Y.C. designed and developed the idea of the paper. J.S. and Y.C. reviewed related previous studies. All authors analyzed the data and wrote the manuscript.

Funding: This research received no external funding. 
Conflicts of Interest: The authors declare no conflicts of interest.

\section{References}

1. Chikishev, E.; Chainikov, D.; Anisimov, I. Increasing the use of natural gas on motor transport by an efficient location of the NGV RS (on the example of Tyumen). IOP Conf. Ser. Earth Environ. Sci. 2017, 50, 012004. [CrossRef]

2. Larionova, M.V. G20: Engaging with International Organizations to Generate Growth. Int. Organ. Res. J. 2017, 12, 54-86. [CrossRef]

3. Mansfield, E. Contribution of R\&D to economic growth in the United States. Science 1972, 175, 477-486. [PubMed]

4. Bilbao-Osorio, B.; Rodríguez-Pose, A. From R\&D to innovation and economic growth in the EU. Growth Chang. 2004, 35, 434-455.

5. Griffin, P.W.; Hammond, G.P.; Norman, J.B. Industrial energy use and carbon emissions reduction: A UK perspective. Wiley Interdisc. Rev. Energy Environ. 2016, 5, 684-714. [CrossRef]

6. Křistková, Z. Impact of R\&D Investment on Economic Growth of the Czech Republic-A Recursively Dynamic CGE Approach. Prague Econ. Pap. 2012, 21, 412-433.

7. Dooley, J.J. Unintended consequences: Energy R\&D in a deregulated energy market. Energy Policy 1998, 26, 547-555.

8. Schuelke-Leech, B.-A. Volatility in federal funding of energy R\&D. Energy Policy 2014, 67, 943-950.

9. Wong, S.L.; Chang, Y.; Chia, W.M. Energy consumption, energy R\&D and real GDP in OECD countries with and without oil reserves. Energy Econ. 2013, 40, 51-60.

10. Bor, Y.J.; Chuang, Y.C.; Lai, W.W.; Yang, C.M. A dynamic general equilibrium model for public R\&D investment in Taiwan. Econ. Model. 2010, 27, 171-183.

11. Scully, G.W. What is the Optimal Size of Government in the United States; Policy Report No.188; Policy Reports: Dallas, TX, USA, 1994; ISBN 1-56808-051-4.

12. Fujimori, S.; Kubota, I.; Dai, H.; Takahashi, K.; Hasegawa, T.; Liu, J.Y.; Hijioka, Y.; Masui, T.; Takimi, M. The Effectiveness of the International Emissions Trading under the Paris Agreement. In Post-2020 Climate Action; Springer: Singapore, 2017; pp. 65-75.

13. Morimoto, S. Analyzing Approaches to Set GHG Reduction Target in Anticipation of Potential 'Further Measures' for International shipping. In Proceedings of the 2017 International Conference on Maritime Energy Management (MARENER), Copenhagen, Denmark, 24-25, January 2017.

14. Nemet, G.F.; Jakob, M.; Steckel, J.C.; Edenhofer, O. Addressing policy credibility problems for low-carbon investment. Glob. Environ. Chang. 2017, 42, 47-57. [CrossRef]

15. Jiang, K.J.; Tamura, K.; Hanaoka, T. Can we go beyond INDCs: Analysis of a future mitigation possibility in China, Japan, EU and the US. Adv. Clim. Chang. Res. 2017, 8, 117-122. [CrossRef]

16. Steinberg, D.; Bielen, D.; Eichman, J.; Eurek, K.; Logan, J.; Mai, T.; McMillan, C.; Parker, A.; Vimmerstedt, L.; Wilson, E. Electrification and Decarbonization: Exploring US Energy Use and Greenhouse Gas Emissions in Scenarios with Widespread Electrification and Power Sector Decarbonization; No. NREL/TP-6A20-68214; National Renewable Energy Laboratory (NREL): Golden, CO, USA, 2017.

17. Goh, T.; Ang, B.W.; Su, B.; Wang, H. Drivers of stagnating global carbon intensity of electricity and the way forward. Energy Policy 2018, 113, 149-156. [CrossRef]

18. Taptich, M.N.; Horvath, A.; Chester, M.V. Worldwide greenhouse gas reduction potentials in transportation by 2050. J. Ind. Ecol. 2016, 20, 329-340. [CrossRef]

19. Patel, P.; Gunderson, V. Deep decarbonization faces deep challenges. MRS Bull. 2017, 42, 632-633. [CrossRef]

20. Raghavan, K.V. Transition to Lower Carbon Energy Regime: Engineering Challenges in Building and Transportation Sectors. In Energy Engineering; Springer: Singapore, 2017; pp. 133-148.

21. Zhang, N.; Wang, B.; Liu, Z. Carbon emissions dynamics, efficiency gains, and technological innovation in China's industrial sectors. Energy 2016, 99, 10-19. [CrossRef]

22. Aden, N. Necessary but not sufficient: The role of energy efficiency in industrial sector low-carbon transformation. Energy Effic. 2018, 11, 1083-1101. [CrossRef]

23. Griffith, R.; Redding, S.; Reenen, J.V. Mapping the two faces of R\&D: Productivity growth in a panel of OECD industries. Rev. Econ. Stat. 2004, 86, 883-895. 
24. Kwon, T.H. The current policy issues for Renewable Portfolio Standard in South Korea. In Heading towards Sustainable Energy Systems: Evolution or Revolution? Proceedings of the 15th IAEE European Conference, Vienna, Austria, 3-6 September 2017; International Association for Energy Economics: Cleveland, OH, USA, 2017.

25. Normile, D. South Korea's nuclear U-turn draws praise and darts. Science 2017, 357, 15. [CrossRef]

26. Dai, H.; Xie, Y.; Liu, J.; Masui, T. Aligning renewable energy targets with carbon emissions trading to achieve China's INDCs: A general equilibrium assessment. Renew. Sustain. Energy Rev. 2017, 82, 4121-4131. [CrossRef]

27. Park, S.; Kang, B.; Choi, M.I.; Jeon, S.; Park, S. A Micro-Distributed ESS-Based Smart LED Streetlight System for Intelligent Demand Management of the Micro-grid. Sustain. Cities Soc. 2017, 39, 801-813. [CrossRef]

28. Coe, D.T.; Helpman, E. International R\&D spillovers. Eur. Econ. Rev. 1995, 39, 859-887.

29. Coccia, M. Political economy of R\&D to support the modern competitiveness of nations and determinants of economic optimization and inertia. Technovation 2012, 32, 370-379.

30. Lichtenberg, F.R.; Siegel, D. The impact of R\&D investment on productivity-New evidence using linked R\&D-LRD data. Econ. Inq. 1991, 29, 203-229.

31. Van Elk, R.; Verspagen, B.; Ter Weel, B.; Van der Wiel, K.; Wouterse, B. A Macroeconomic Analysis of the Returns to Public RED Investments; CPB Netherlands Bureau for Economic Policy Analysis: Hague, The Netherlands, 2015.

32. Wang, H.; Wu, D. An Explanation for China's Economic Growth: Expenditure on R\&D Promotes Economic Growth-Based on China's Provincial Panel Data of 1997-2013. J. Serv. Sci. Manag. 2015, 8, 809.

33. Bianchi, M.; Croce, A.; Dell'Era, C.; Di Benedetto, C.A.; Frattini, F. Organizing for Inbound Open Innovation: How External Consultants and a Dedicated R\&D Unit Influence Product Innovation Performance. J. Prod. Innov. Manag. 2016, 33, 492-510.

34. Stemberkova, R.; Zdralek, P.; Matulova, P.; Maresova, P.; Kuca, K. The Importance of the Evaluation of R\&D in Relation to the Competitiveness of the Czech Republic. In Business Challenges in the Changing Economic Landscape; Springer: Cham, Switzerland, 2016; Volume 2, pp. 55-67.

35. Organization for Economic Cooperation and Development (OECD). Main Science and Technology Indicators. 2017. Available online: https:/ / stats.oecd.org/Index.aspx?DataSetCode=MSTI_PUB (accessed on 25 May 2018).

36. Korea Institute of S\&T Evaluation and Planning (KISTEP). Survey of Research and Development in Korea; KISTEP: Seoul, South Korea, 2017. (In Korean)

37. Gwartney, J.; Holcombe, R.; Lawson, R. The scope of government and the wealth of nations. Cato J. 1998, $18,163$.

38. Davies, A. Human development and the optimal size of government. J. Socio-Econ. 2009, 38, 326-330. [CrossRef]

39. Pevcin, P. Does Optimal Size of Government Spending Exist? University of Ljubljana: Ljubljana, Slovenia, 2004; Volume 10, pp. 101-135.

40. Facchini, F.; Melki, M. Optimal Government Size and Economic Growth in France (1871-2008): An Explanation by the State and Market Failures; Sorbonne University: Paris, France, 2011.

41. Langford, I.H.; Bateman, I.J.; Jones, A.P.; Langford, H.D.; Georgiou, S. Improved estimation of willingness to pay in dichotomous choice contingent valuation studies. Land Econ. 1998, 74, 65-75. [CrossRef]

42. Perry, R.W.; Skalski, J.R.; Brandes, P.L.; Sandstrom, P.T.; Klimley, A.P.; Ammann, A.; MacFarlane, B. Estimating survival and migration route probabilities of juvenile Chinook salmon in the Sacramento-San Joaquin River Delta. N. Am. J. Fish. Manag. 2010, 30, 142-156. [CrossRef]

43. Jones, B.A.; Ripberger, J.; Jenkins-Smith, H.; Silva, C. Estimating willingness to pay for greenhouse gas emission reductions provided by hydropower using the contingent valuation method. Energy Policy 2017, 111, 362-370. [CrossRef]

44. Ratner, J.B. Government capital and the production function for US private output. Econ. Lett. 1983, 13, 213-217. [CrossRef]

45. Adofu, I.; Taiga, U.U.; Tijani, Y. Manufacturing Sector and Economic Growth in Nigeria (1990-2013). Donnish J. Econ. Int. Financ. 2015, 1, 001-006.

46. Hibbs, D.A. Problems of statistical estimation and causal inference in time-series regression models. Sociol. Methodol. 1973, 5, 252-308. [CrossRef]

47. Cochrane, D.; Orcutt, G.H. Application of least squares regression to relationships containing auto-correlated error terms. J. Am. Stat. Assoc. 1949, 44, 32-61. 
48. Pakes, A.; Schankerman, M. The rate of obsolescence of patents, research gestation lags, and the private rate of return to research resources. In RED, Patents, and Productivity; University of Chicago Press: Chicago, IL, USA, 1984; pp. 73-88.

49. Kim, E.J. Analysis of growth factors of Korean manufacturing industry. Policy Res. 1999, 18, 1-227. (In Korean)

50. Sengupta, R.; Gupta, M. Developmental sustainability implications of the economic reforms in the energy sector. In India and Global Climate Change: Perspectives on Economics and Policy from a Developing Country; Routledge: Abingdon-on-Thames, UK, 2003; Volume 36.

51. Watson, G.S.; Durbin, J. Exact tests of serial correlation using noncircular statistics. Ann. Math. Stat. 1951, 22, 446-451. [CrossRef]

52. Savin, N.E.; White, K.J. The Durbin-Watson test for serial correlation with extreme sample sizes or many regressors. Econ. J. Econ. Soc. 1977, 45, 1989-1996. [CrossRef]

53. Dorn, D.; Katz, L.F.; Patterson, C.; Van Reenen, J. Concentrating on the Fall of the Labor Share. Am. Econ. Rev. 2017, 107, 180-185.

54. Sengupta, R. Third Industrial Revolution and India's Approach to Sustainable Energy Development. In Global Economic Cooperation; Springer: New Delhi, India, 2016; pp. 141-163.

55. Schill, W.P.; Zerrahn, A.; Kunz, F.; Kemfert, C. Decentralized solar prosumage with battery storage: System orientation required. DIW Econ. Bull. 2017, 7, 141-151.

56. Buessler, S.; Badariotti, D.; Weber, C. Evaluating the complex governance arrangements surrounding energy retrofitting programs: The case of collective ownership buildings in France. Energy Res. Soc. Sci. 2017, 32, 131-148. [CrossRef]

57. Pichet, É. Finance Laws: Stability of Fiscal and Budgetary Policies and Control of the Structural Balance; Bordeaux IV University: Pessac, France, 2016.

58. Connor, P.M.; Baker, P.E.; Xenias, D.; Balta-Ozkan, N.; Axon, C.J.; Cipcigan, L. Policy and regulation for smart grids in the United Kingdom. Renew. Sustain. Energy Rev. 2014, 40, 269-286. [CrossRef]

59. Newbery, D.M. Towards a green energy economy? The EU Energy Union's transition to a low-carbon zero subsidy electricity system-Lessons from the UK's Electricity Market Reform. Appl. Energy 2016, 179, 1321-1330. [CrossRef]

60. Rehman, S.; Hussain, Z. Renewable Energy Governance in India: Challenges and Prospects for Achieving the 2022 Energy Goals; University Library of Munich: Munich, Germany, 2017.

61. Alemán-Nava, G.S.; Casiano-Flores, V.H.; Cárdenas-Chávez, D.L.; Díaz-Chavez, R.; Scarlat, N.; Mahlknecht, J.; Dallemand, J.F.; Parra, R. Renewable energy research progress in Mexico: A review. Renew. Sustain. Energy Rev. 2014, 32, 140-153. [CrossRef] 